\title{
Neuropathy, Hereditary Sensory and Autonomic, Type V
}

National Cancer Institute

\section{Source}

National Cancer Institute. Neuropathy, Hereditary Sensory and Autonomic, Type V. NCI Thesaurus. Code C156360.

An autosomal recessive condition caused by mutation(S) in the NGF gene, encoding beta-nerve growth factor. It is characterized by loss of pain sensation, particularly in the extremities. 